\title{
DIASPORIC IDENTITY(IES) AND THE MEANING OF HOME IN AUTOBIOGRAPHICAL DOCUMENTARY FILMS*
}

\author{
Isabel Macedo \\ Universidade do Minho, Portugal \\ Rosa Cabecinhas \\ Universidade do Minho, Portugal
}

\begin{abstract}
Reconstructed in social contexts, the memories of forced migration experiences such as those lived by filmmakers Diana Andringa and António Escudeiro - who had to leave Angola, the country where they had been born and raised - are now being highlighted, shared, and negotiated in the current audiovisual context. The documentaries analyzed in this work, Escudeiro's Goodbye, Until Tomorrow (2007) and Andringa's Dundo, Colonial Memory (2009), allow us to reflect on how these memories of migration experiences are portrayed in contemporary Portuguese cinema. In this article, we argue that autobiographical narratives - oral and visual - are privileged sites for investigating cultural identity and its construction. Our thematic analysis of these two documentaries was complemented by an in-depth interview with the authors. This multi-method approach allowed us to investigate the social and cultural contexts in which they lived, as well as the meanings of home and belonging to the two filmmakers.
\end{abstract}

Keywords: Autobiographical documentaries; memory; home; identity.

\section{Introduction}

Autobiographical documentaries that focus on the events of the colonial period allow for the analysis of the narratives of those who live and have lived within and between cultures (Bhabha, 1994) - due to the processes of colonisation and forced migration. This is the case with filmmakers António Escudeiro and Diana Andringa, both of whom have directly experienced forced migration, developing distinctive identities and social relations within and across countries. Through their audiovisual narratives and by relating images (spaces) to discourse, we have gained a more precise insight into the identity process and the concept of home. The documentaries analyzed in this paper (Goodbye, Until Tomorrow [2007; Appendix A] by António Escudeiro and Dundo, Colonial Memory [2009; Appendix B] by Diana Andringa) allow us to reflect on the role of migration experiences in the process of identity (re)construction, as well as their impact on everyday life. These two filmmakers are people who were forced to leave their home country of Angola for Portugal. Both returned to Angola after several

\footnotetext{
* Paper developed under the research project "Identity Narratives and Social Memory: the (re)making of lusophony in intercultural contexts" (PTDC/CCI-COM/105100/2008), and the PhD Scholarship SFRH/BD/75765/2011, supported by the Portuguese Foundation for Science and Technology.
} 
decades to review the spaces of the past and confront their own memories. Their documentaries seek to portray these return journeys.

In this paper, we reflect on the concepts of autobiographical memory, cultural identity, and home. Through thematic analysis (Braun \& Clarke, 2006) of the selected documentaries, our main concern is to examine the contexts and meanings of the messages produced. This approach allows us to locate the themes related to the concepts of identity, belonging, and home within the audiovisual narratives.

Furthermore, semi-structured interviews with the filmmakers enable us to understand the relationship between migration and identity by discussing what being at home and leaving home meant to the two interviewees. Two types of homes were found in their oral and audiovisual narratives: the real home referring to domestic and familiar spaces, for many years unreachable because of the Angolan civil war, and the symbolic home, connected to memories of exile and nostalgia.

\section{The Social Character of Memory}

Maurice Halbwachs' seminal work on the interplay between individual memory and collective memory is of major importance. The author argues that there are no purely individual memories, since all memories are formed within a group setting. Halbwachs argues that memory is mainly a collective process; this is so also for memories which seem to be private and personal. In other words, memories that involve no other person but only experiences in which the individual was alone are still essentially collective, for they exist only because de individual's mind is organized by a social process and perceives and remembers within a social context. Thus, "no memory is possible outside frameworks used by people living in society to determine and retrieve their recollections" (1952/1992: 43). The individual remembers by placing himself at the viewpoint of the group and group memory realizes and manifests itself in the memories of individuals.

Following this perspective, what we see today is taking place within the framework of our old memories, which adapt to our current perceptions. Since the collective memory is essentially a reconstruction of the past in the light of the present, we preserve some memories of our lives, which are continually reproduced. Through them "a sense of our identity is perpetuated" (Halbwachs, 1952/1992, p.47).

According to Halbwachs (1952/1992), one cannot think about the events of one's past without discoursing upon them. In fact, language has a key role in the reconstruction of our pasts. How do we locate our memories? With the help of reference points that we 
carry with us. As we look around or think of others, we can find ourselves in those times and spaces once again. Fivush (2008) emphasizes this social nature of memory. According to this perspective, memory in general and autobiographical memory in particular are built on social interactions in which specific interpretations of events are highlighted, shared, negotiated, and contested, leading to fluid, dynamic representations of the events of our lives and helping us to define ourselves, others, and the world. It is through language that autobiographical memory is expressed and personal memory organized.

The stories we tell about our lives define who we are as individuals within families, cultures, and historical periods. To Fivush (2008), there are two critical developmental periods: the preschool years, when the self begins to emerge, and adolescence, when autobiographical memories are moved into the narrative of global life by which we define ourselves, others, and our values. In adolescence, we see the beginning of a narrative that connects life events over time and places them in relation to one another, creating a set of interrelated stories. For Fivush (2008), individuals put their own life stories into the context of family history, which enables them to understand themselves as members of a family that extends beyond their birth. Their own stories are therefore embedded within the stories of others, past and present.

Keeping in mind the social character of memory, it is important to understand how the memories of people who have lived through forced migration have been reconstructed in audiovisual forms. Knowing which influences have been exerted over them renders these narratives important sites for analyzing the identity process. Documentary films, particularly autobiographical ones, can help us to simultaneously conserve a factual record of events and approach all these events and the phenomena that surround them in a more holistic way (Reia-Baptista, 2010).

\section{Autobiographical Memories of Colonial Past}

Reflecting on discourses about the past requires a critical view of our own perspectives - a process of gradual distancing with respect to the event in question, a decentration from our own perspective - and the progressive inclusion of the perspectives of others, as well as the coexistence of a plurality of possibly conflicting memories. Further, the "Other" must be recognized as potential partner (Licata, Klein, \& Gély, 2007). This statement is even more significant when studying memories of past conflicts, such as colonial wars, which can be an obstacle to dialogue between groups that compromises their future relations. Proper management of collective memories - often contradictory and plural - is crucial to the success of the reconciliation process and the possibility of 
an effective dialogue with the "other" (Cabecinhas \& Feijó, 2010). In fact, collective memory plays an important role in the present-day relationships between former colonizers and the former colonized.

Indeed, as L'Éstoile (2008) argues, the colonial past is present in Europe, as in excolonized regions around the globe. It is embodied not only in material culture, in monuments, libraries, architecture, and museum collections, but also in images and people. It shapes politics, economics, artistic and intellectual life, linguistic practices, and senses of belonging. It also informs the rhetoric and the categories mobilized when Europeans deal with migrants from other continents.

The Portuguese colonial empire was the last to fall, in 1975. The idea of empire was firmly implanted in the country's national consciousness and served as one of the main sources of national pride (Corkill \& Almeida, 2009; Sobral, 2010). Even though the concept of "empire" disappeared from the public discourse in the 1950s, several authors argued this was mainly a modification in the terminology, with no structural changes. The repeal of the Colonial Act in 1951 make it official, the "colonies" began to be called "overseas provinces" and Portugal was redefined as a "multi-continental nation", a "decisive reassertion of national unity", according to Carvalheiro (2011, p. 205), with no substantive changes in the way the "overseas provinces" were administered, or in the public perceptions.

The official discourses of national identity highlight what the Portuguese have given to others and not what they have received from them (Almeida, 2002). In fact, fifty years of dictatorships, colonial wars, and the lusotropicalist myth have marked Portuguese self-representations throughout the post-colonial period. Vala, Lopes and Lima (2008) maintain that some racism in Portugal is a lingering consequence of the Lusotropicalist ideology. This alleged dimension of the Portuguese national character was created and spread by the anthropologist Gilberto Freyre (1933/2002), when he proposed the concept of Lusotropicalism to explain the apparent success of relations among different cultures in Brazil. This ideology is based on the supposed existence of a specific Portuguese cultural trait: the natural capacity and ability of the Portuguese to relate to people they see as different. This trait that would explain the "unique character of colonial relationships, and that would, nowadays, have a positive impact on the relationships between Portuguese and immigrants" (Vala, Lopes, \& Lima, 2008, p. 289).

However, recent research reveals that newer, more sophisticated forms of racism have emerged, producing many everyday discriminatory actions, at institutional and 
interpersonal levels (Cabecinhas, 2010; Pereira \& Vala, 2012). Seeking to understand the persistence of the Lusotropicalist viewpoint, Mendes and Valentim (2012) studied history school textbooks published in Portugal between 1965 and 1972, in the attempt to verify whether these ideas remained disseminated within Portuguese society. The authors found that there are very clear references to harmonious coexistence among peoples and, above all, an affirmation of colonized peoples as Portuguese, separated only by customs and skin color. Araújo and Maeso (2012) also studied Portuguese history textbooks, analyzing the five most popular textbooks for the $2008-2009$ school year, at Key Stage 3 (Years 7, 8, and 9, for pupils aged 12-15). The authors found that the textbooks' master narratives constituted a power-evasive discourse of history that naturalized core processes such as colonialism and racism.

In the context of these enquiries, we considered it important to study not only school textbooks but also films, and to examine their roles in the dissemination of social representations about national identity and in the construction of collective memories. As Sonja de Leeuw states, by the end of the 1980 s and in the 1990 s the use of testimonies and the role of witnesses became crucial in reshaping collective memory; "documentary filmmaking has taken the opportunity to present individual stories as representations of memory, providing a variety of discourses of memory, a variety of truths" (2007: 81).

Autobiographical documentaries that focus on forced migration experiences, such as those studied in this article, are tools that permit us to analyze identity dynamics by examining the effects of these displacement experiences on people's lives. They also offer an opportunity to increase our knowledge and expand our perceptions of the various experiences of individuals who have lived or live "in-between" cultures (Bhabha, 1994), helping to transform mutual representations and images from the colonial past. Therefore, we argue that the production and dissemination of documentaries based on autobiographical memories reveal other versions of history, told in the first person, which, when integrated into our knowledge of the past, will enable a better understanding of historical events and their meanings for different sociocultural groups (Macedo, Cabecinhas, \& Abadia, 2013).

\section{Media, Cultural Identity, and the Meaning of Home}

Media and communication technologies play an important role in the cultural identity process. They construct images, text, and sounds that mediate relations within specific communities, connections among members of displaced groups, and communications between different cultural groups and individuals (Bailey, Georgiou, \& Harindranath, 
2007). Increasingly, imagination and mediation have become tightly interlinked to processes of globalization - especially the intense mobility of people, ideas, images, and sounds. Transnational media have become a means of transporting and translating ideologies and cultural repertoires beyond physical boundaries. Visual culture offers diasporic populations the opportunity to identify with their concepts of homeland, emphasizing common affiliations and identifications (Moorti, 2003). Accordingly, to the two filmmakers, the films produced might help to forge feelings of "belonging" and "bridging”, creating symbolic spaces for political expression, senses of inclusion or exclusion, and hybrid identity articulations (Bailey, Georgiou, \& Harindranath, 2007).

With regard to the identity concept, most authors agree that identity is a complex and multidimensional notion that should not be understood as "transparent". Hall (1993) considers that we must understand the concept of identity as a "production", that is, as an always incomplete process in which our representations of others and of our experiences are significant. He adds that "identities are the names we give to the different ways we are positioned by, and position ourselves within, the narratives of the past" (Hall, 1993, p. 225). According to Hall (1993), it is only from this position that we can properly understand the traumatic character of the colonial experience. The past is always constructed through memory, fantasy, narrative, and myth, and cultural identities are the points of identification and positioning within the discourses of history and culture:

In terms of colonialism, underdevelopment, poverty, and the racism of colour, the European presence is that which, in visual representation, has positioned the black subject within its dominant regimes of representation: the colonial discourse, the literatures of adventure and exploration, the romance of the exotic, the ethnographic and traveling eye, the tropical languages of tourism, travel brochure and Hollywood and the violent, pornographic languages of ganja and urban violence (Hall, 1993, p. 232-233).

Hall theorized identity as within, not outside, representation, and hence saw cinema not as a mirror held up to reflect what already existed but as another form of such representation (1993). The two films studied in this article constitute specific spaces of representation and identity reconstruction. They are personal and unique, like fingerprints, because they are both authorial and autobiographical. They can be included in what Naficy (2001) considered an accented cinema, in which identity is not a fixed essence but a process of becoming, even a performance of identity. As the author argues, accented films emphasize: 
visual fetishes of homeland and the past (landscape, monuments, photographs) (...), as well as visual markers of difference and belonging (posture, look) (...), they equally stress the oral, the vocal, and the musical (...) which also demarcate individual and collective identities (Naficy, 2001, p. 24-25).

A question often encountered in our daily lives and directly related to how we identify ourselves is "Where are you from?". The answer relies on our points of identification and networks of belonging. Therefore, what does it mean for people like Diana Andringa and António Escudeiro, who have endured forced migration, to be at home? How are the meanings of home and belonging represented through their audiovisual narratives?

In an insightful paper titled "Home and Away: Narratives of Migration and Estrangement", Sara Ahmed (1999) reflects on the relationship between migration and identity. She states that home is implicitly constructed as a "purified space of belonging in which the subject is too comfortable to question the limits or borders of her or his experience" (Ahmed, 1999, p. 339). However, the concept of home is also a mythical place of desire in the diasporic imagination. In this sense, it is a place of no return, even if it is possible to visit the geographical territory that is seen as home. On the other hand, home is the lived experience of a locality, including its sounds, and smells (Brah, 1996).

As Ahmed (1999) argues, the "narrative of leaving home produces too many homes and hence, no place in which memory can allow the past to reach the present (in which the 'I' could declare itself as having come home)" (p. 330-331). The author refers to home as a skin, suggesting that the boundary between one's self and home is permeable, and that the boundary between home and away is permeable as well. According to this perspective, "Movement away is always affective: It affects how 'homely' one might feel and fail to feel" (Ahmed, 1999, p. 341). It is impossible to return to a place that was lived as "home" according to Ahmed (1999), because one's home is not outside of one's self, but part of it. Indeed, the movements of individual selves between places that come to be inhabited as homes involve the "discontinuities of personal biographies and wrinkles in the skin" (Ahmed, 1999, p. 341). The migratory experience of leaving home can therefore be defined as follows:

Failure of memory to fully make sense of the place one comes to inhabit, a failure which is experienced in the discomfort of inhabiting a migrant body, a body which feels out of place, which feels uncomfortable in this place (Ahmed, 1999, p. 341). 
The process of returning home, as Escudeiro and Andringa did, is similarly about the failures of memory, specifically of memories not being inhabited in the same way by what appears to be familiar (Ahmed, 1999, p. 344). The issue is that home is not simply about fantasies of belonging -one's location of origin - but rather, it is sentimentalized as a space of belonging. We agree with Ahmed (1999) when she states that the questions of home and being at home can only be addressed by considering the issue of affect. Both films are constituted by the structures of feeling of the filmmakers themselves as displaced subjects. Hence, affect is often present, as we will see, in the visual narratives we examined, although it is even more visible in the oral narratives of the two filmmakers. This is due to the more spontaneous nature of oral narrative, compared to the structured and reworked character of films.

\section{Where is Home? Reflections on Memory, Space, and Belonging}

Starting with the importance given to autobiographical documentaries as instruments enabling reflections on identity reformation, we decided to examine Escudeiro's documentary Goodbye, Until Tomorrow and Adringa's Dundo, Colonial Memory. To complete this analysis, we also developed in-depth interviews with the filmmakers. It is important to draw attention to the fact that these documentaries are specific records of reality and that the people who produced them had specific points of view on the subject matter as well as scripts guiding their production. Thus, it is not a viewpoint that can be generalized, yet it allows us to explore some of the identity dynamics that resulted from the migration processes in the (post)colonial period.

Goodbye, Until Tomorrow is the story of Escudeiro's return to Angola. This film intersects and confronts two visual worlds: the director's memoirs and modern Angola. As the author states early in the film, "Sept. 15, 1975, I was forced to leave Angola. Thirty-two years after, I returned. From this return and others, I got this look" (Goodbye, Until Tomorrow, 2007). The film is intended to show the cities and places in Angola that marked the author life. As Escudeiro mentions in his interview, "I wanted to make a film that was somewhat my Angolan geography"' (Escudeiro, interview, Feb. 8, 2013). This statement can be analyzed using Halbwach's (1950/1990) idea that space is a lasting reality. In this sense, to reclaim our past, we need to see the environment around us in order to evoke past memories. For Escudeiro, "space" refers to what he went through and the buildings from the past reappear in various memory categories.

\footnotetext{
${ }^{1}$ In Angola, the author lived by the sea, where morning baths on the beach were a daily ritual. His house in Lisbon, where the interview was conducted, is filled with photographs and objects related to Angola and the spaces portrayed within the documentary.
} 
This relationship between space and memory is very present in the author films and oral narratives.

This street, the house that was not there, was my world. I lived here my childhood with my sisters, my father, and my mother (Goodbye, Until Tomorrow, 2007).

The garage, the skating rink, tennis court, are images of an inexplicable survival, ask a glance at the magic of their timelessness (Goodbye, Until Tomorrow, 2007).

These two excerpts, as those that follow bring to the discussion the concept of accented cinema. Naficy (2001) refers that many accented films emphasize territoriality, rootedness, and geography. In fact, because the filmmakers were displaced, these films are deeply concerned with territory and territoriality. Their preoccupation with place and homeland tends to emphasize boundlessness and timelessness, and it is expressed by means of nostalgic longing to the homeland's natural landscape, monuments, and souvenirs.

On the border of unbelievable, I review the Lobito Sport Club. The memory is no longer memory, and today brings the Carnival celebrations, evening dances, the dances and movie night on Tuesdays and Saturdays. Here, I saw the first movie of my life (Goodbye, Until Tomorrow, 2007).

Finally, the Benguela Railway, the center of everything. Kid, playing trains, watching them depart and arrive. My father came to Angola to work on the final section of the line from Lobito to Luau $-1,357 \mathrm{~km}$ stretched. Civil war stopped the train for 30 years. Today, via Lobito to Huambo and Cubal the Calenga; tomorrow will be Luau. Having reached director, left in railways 40 years of his life (Goodbye, Until Tomorrow, 2007).

Similarly to those of António Escudeiro, the memories associated with the physical spaces where Diana Andringa lived for 11 years are also highlighted, both throughout her documentary and her interview. The excerpts that follow allow us to understand how this director was affected by physical and social places, and also by the elements that comprised them:

The fantastic roast beef that my godmother cooked - at the time, I liked meat well done, but even rare, it tasted fantastic. I remember the mayonnaise was fantastic, the taste of potato chips. Those flavors - I have them all - mangoes, pineapples, papayas, the breakfast (Andringa, interview, Jan. 6, 2012).

Then I remember stupid things, but that was perhaps later at the second house that I remember, so this was life in K10. I remember a beautiful palm tree at the end of 
our street; I mean, I remember the sounds, smells, all those things, plants, animals (Andringa, interview, Jan. 6, 2012).

Those are the memories of the earth; you know, the red soil is completely different from the soil here, and then there were the rivers. There was the humidity itself (Andringa, interview, Jan. 6, 2012).

On the relationship between space and collective memory, Halbwachs (1952/1992) introduces the notion of space beyond its geographical understanding to a place of memory production surrounded by symbolism. Space is not only the place of memory but also a means of expressing changes in group dynamics over time. In fact, the buildings that Escudeiro presents in his film, marred by bullets because of the Angolan civil war, reveal changes to Angolan society.

It is interesting to see that the spaces that the director visits allow him to relive old memories, such as the Benguela Railway, a structure that marked his childhood and professional life, and his father's career path. Escudeiro worked for several years on the "paying train" where payments were made to railway employees. The author was responsible for these collections. In the interview, he tells us, "How I liked to spend receipts" (Escudeiro, interview, Feb. 8, 2013). In this moment, recalling this period of his life, emotion was displayed in his facial expression. Therefore, the questions of home and being at home, when individuals recall past memories, are closely linked to affect, as argued by Ahmed (1999). The emotional tone is also meaningful when Escudeiro refers to the cinema of Ruacana and to the Huambo house.

On the main street, the Ruacana, cinema of all movies, is the hurt ruin of that city that expects new destinations (Goodbye, Until Tomorrow, 2007).

Coming countless times, comes the Huambo home. Who are these rooms that were ours? Who is this balcony? How much rain, how many storms, how many rays befell this house, 90 years old? What are these meetings? (Goodbye, Until Tomorrow, 2007).

Andringa returned to Dundo in 2008 in order to confront her memories, to see "if they were real" and to reencounter the places of her childhood, although she was aware that they could have changed significantly compared to what she had left behind more than 50 years before. For this author, it was social inequality that marked her childhood experiences in Dundo. Emotions and memories are displayed within her documentary and in her interview, where she recalls several episodes. For instance, Andringa recalls an event related to a servant she loved who had been accused of stealing a piece of clothing from a neighbor: "He was black, passing by. The garment vanished, so he was 
arrested, beaten up to confess, and they beat him so hard...” (Andringa, interview, Jan. 6, 2012).

I remember his hands so red from the slapping he had taken, swollen hands, and I remember my father, who was a distant person, look at him, pick up his hands, look at him, apologize, and burst into tears. I just saw my father cry for two or three times, but I remember that day, my father was so embarrassed. This is a shame that penetrates us, because it is a shame that there are people that somehow you perceive that it is on your behalf that they do those things, that you can beat up that person (Andringa, interview, Jan. 6, 2012).

In fact, it is precisely because of this affective relationship and the set of meanings related to contexts, facts, and individuals that we can properly understand the plurality of collective memories during the colonial period. This affective relationship is also noticeable in Escudeiro's documentary, when one individual tells him that he had met his father, a "good engineer": "I want to see this gentleman; this gentleman is ours" (Goodbye, Until Tomorrow, 2007). The author says, "In these words only, I found one of the reasons, perhaps the stronger for being here now" (Goodbye, Until Tomorrow, 2007). Reflecting on where home is for him, Escudeiro responds without hesitating:

My land is Angola; I was not born here. It is not that I don't like Lisbon. Lisbon is a very beautiful city, but I feel inside of me. (...) I have always Angola as my land. Just look around you; it's not exhibitionism, it is memory. I have boxes and boxes and boxes of photographs of Angola (Escudeiro, interview, Feb. 8, 2013).

When recalling his family, the author adds that he is convinced that his "father died of longing for Africa. His soul, if it exists, remains in Angola” (Escudeiro, interview, Feb. 8, 2013).

Andringa's homeland is not Lisbon either, because "Lisbon is no man's land" (Andringa, interview, Jan. 6, 2012). Even her parents' house in Portugal does not have the same meaning for the filmmaker, "because it is not there that you are raised. So physically, I, despite being white, despite not being tchokwe, despite all this, I am clearly Angolan. Culturally, I am a mixed thing" (Andringa, interview, Jan. 6, 2012). As can be seen from the filmmakers excerpts, 'home' incorporates a focus on a multiplicity of levels, including the individual, family, community, society, and nation; it also functions as an indicator of the spatial aspect or geographic location of imagined belonging (Walder, 2011).

Reflecting on who she really is, Andringa tells us she is a citizen of the world: 
This is a very friendly way of saying that I am a stateless person. (...) That is, what I am is a person without land, a stateless person. It is a person who is constantly in need of their own country (Andringa, interview, Jan. 6, 2012).

People may and do often feel alienated from the place where they are; specially if, like Andringa and Escudeiro, they have been obliged to depart from their place of birth and upbringing, and make a new home elsewhere. Naficy (2001) argues that to overcome this anxiety many colonial and postcolonial filmmakers have tried to re-imagine or recreate their homelands. The author adds that as a result, the nurturing of a collective memory, often of an idealized homeland, is constitutive of the diasporic identity.

Andringa considers herself physically Angolan, having repeated this idea several times throughout her narrative, and states that she needs:

A sense of space that is not this one; here, I feel closed and oppressed. I feel like I am always being watched. Therefore, I need that sense of space; I need the concept of heat. (...) I need green, I need plants, and I practically only like tropical plants (Andringa, interview, Jan. 6, 2012).

Andringa belongs to that space. Home, for her, seems to be associated with the lived experience of locality and its sounds and smells (Brah, 1996).

Throughout the interviews and documentary analyses, we find one idea that seems to permeate these narratives. Although both filmmakers returned to the land where they were born and lived for years, the return home is not completely achieved. Indeed, as Ahmed (1999) argues, it is impossible to return to a place where one once lived as home, because the home is not independent of the self. They returned to their physical homes, for many years unreachable because of the civil war. Nevertheless, the symbolic home, connected to their memories of exile and nostalgia (affections) can only be remembered and imagined. In fact, reconstructions of the past can only be approximations (Halbwachs, 1950/1992), but visual culture can help to create networks and affective ties between diasporic populations around the world.

Furthermore, documentaries like those analyzed in this paper enable us to understand on how identity is formed and transformed through forced displacement experiences, especially when this process occurs in critical development periods like adolescence, as was the case for Andringa, who left Angola when she was 11. The two films reveal positions on the events of the past and, by allowing us to recognize their different stories, enable us to construct our own points of identification and perhaps revise our views about this period of history. 


\section{Final Thoughts}

The experiences lived in the colonial period, have been disseminated by museums, literature, films, and other cultural memory artefacts. Public memory of this time is proliferating in Portuguese documentary films. Depending on where these memories are (re)constructed and by whom, these products remember the past according to a variety of national ideals and political needs. All reflect both, the past experiences and current lives of their communities.

It is important to go further with this research, looking to analyze the role of these films in the reinforcement or in the deconstruction of lusotropicalist ideology, examining how this myth is spread in contemporaneous Portuguese cinema.

These two films share some features with the authors, which may be included in Naficy (2001) notion of accented cinema, authorial and autobiographical, increasingly present in the Portuguese current cinematography.

This work reveals also the importance of analyzing the collective memories of people who have lived through displacement experiences. These experiences have decisively marked the identities of the filmmakers in both their personal and professional lives. In our opinion, these and other autobiographical documentaries are relevant instruments for studying the processes of identity reconstruction in individuals who have had migratory experiences, and when shared with the public, they may contribute to reformulating representations of this historical period. In fact, films are not consumed in isolation. Today, they generate other forms of historical representation: books about movies, reviews, magazines, documentaries, websites, and educational materials, among others. In this sense, these films have certain inherent properties: They draw viewers into a specific narrative about the past, move them between laughter and tears, developing particular images in their minds. They also have the ability to evoke intense identifications in us through their depictions of certain experiences of forced migration during the colonial period, contributing to the revision of our perceptions and to the construction of a more diverse collective historical memory. Indeed, the specific form of reception which turns films into memory-making is not an individual but a collective phenomenon. On a collective level, films can become powerful media, whose versions of the past circulate in large parts of a given society, and even internationally. On an individual level, media representations provide those schemata and scripts which allow us to create in our minds certain images of the past and which may even shape our own experiences and autobiographical memories. 


\section{References}

Ahmed, S. (1999). Home and away. Narratives of migration and estrangement. International Journal of Cultural Studies, 2 (3): 329-347.

Almeida, M. V. (2002). 'Longing for oneself': Hybridism and Miscegenation in Colonial and Postcolonial Portugal. Etnográfica, VI (1), 181-200.

Andringa, D. (Director) (2009) Dundo, Colonial Memory (Documentary). Portugal: Movies LX.

Araújo, M. \& Maeso, S. R. (2012). History textbooks, racism and the critique of Eurocentrism: beyond rectification or compensation. Ethnic and Racial Studies, 35 (7), 1266-1286.

Bailey, O., Georgiou, M. \& Harindranath, R. (2007). Transnational lives and the media: re-imagining diasporas. New York: Palgrave Macmillan.

Bhabha, H. K. (1994). The Location of Culture. London: Routledge.

Brah, A. (1996). Cartographies of Diaspora: Contesting Identities. London and New York: Routledge.

Braun, V. \& Clarke, V. (2006). Using thematic analysis in psychology. Qualitative Research in Psychology, 3, 77-101.

Cabecinhas, R. (2010). Expressões de racismo: mudanças e continuidades. In: Mandarino, A.C.S. \& Gomberg, E. (Eds.) Racismos: Olhares plurais (pp.11-43). Salvador: Editora da Universidade Federal da Bahia.

Cabecinhas, R., \& Feijó, J. (2010). Collective memories of Portuguese colonial action in Africa: Representations of the colonial past among Mozambicans and Portuguese youths. International Journal of Conflict and Violence, 4 (1), 28-44.

Carvalheiro, J. R. (2011) Portugalidade e diferença: esboço para um arquivo simbólico das percepções raciais. In Barata, A., Pereira, A. S., \& Carvalheiro, J. R. (Eds.), Representações da Portugalidade (pp. 197-219). Caminho: Lisboa.

Corkill, D. \& Almeida, J. (2009). Commemoration and Propaganda in Salazar's Portugal: The Mundo Português Exposition of 1940. Journal of Contemporary History, 44 (3), 381-399.

de Leeuw, S. (2007) Dutch documentary film as a site of memory: Changing perspectives in the 1990s. European Journal of Cultural Studies, 10(1), 75-87.

Escudeiro, A. (Director) (2007) Godbye, until Tomorrow (Documentary). Portugal: Real Ficção.

Fivush, R. (2008). Remembering and reminiscing: How individual lives are constructed in family narratives. Memory Studies, 1.1, 49-58.

Freyre (1933/2002). Casa-grande \& Senzala: edição crítica. G. Giucci, E. R. Larreta \& E. N. Fonseca (Eds.). Madrid: ALLCA XX. 
Halbwachs, M. (1952/1992). On collective memory. Chicago: The University of Chicago Press. Translated by Lewis A. Coser, from Les cadres sociaux de la mémoire, Presses Universitaires de France, Paris, 1952.

Hall, S. (1993). "Cultural identity and diaspora”. In P. Williams and L. Chrisman (Eds.), Colonial Discourse and Post-Colonial Theory: a Reader (pp. 392-401). London: Harvester Wheatsheaf.

L'Estoile, B. (2008). The Past as it Lives Now: an Anthropology of colonial legacies. Social Anthropology, 16 (3), 267-279.

Licata, L., Klein, O., \& Gély, R. (2007). Mémoire des conflits, conflits de mémoires: Une approche psychosociale et philosophique du role de la mémoire collective dans les processus de réconciliation intergroupe. Social Science Information, 46 (4), 563-89.

Macedo, I., Cabecinhas, R., \& Abadia, L. (2013). Audiovisual Post-colonial Narratives: Dealing with the Past in Dundo, Colonial Memory. In R. Cabecinhas \& L. Abadia (Eds.), Narratives and Social Memory: Theoretical and Methodological Approaches (pp. 159174). Braga: University of Minho.

Mendes, V., \& Valentim, J. (2012). O luso-tropicalismo nos manuais de História e de Português do ensino primário português no período colonial: um estudo exploratório. Psicologia e Saber Social, 1 (2), 221-231.

Moorti, S. (2003). Desperately Seeking an Identity: Diasporic Cinema and the Articulation of Transnational Kinship. International Journal of Cultural Studies, 6 (3), 355-376.

Naficy, H. (2001). An accented cinema: exilic and diasporic filmmaking. Princeton and Oxford: Princeton University Press.

Pereira, C. \& Vala, J. (2012). Racism: an evolving virus. In Betthencourt, F. \& Pearce, A. J. (Eds.), Racism and ethnic relations in the portuguese-speaking world (pp. 49-70). New York: Oxford University Press.

Reia-Baptista, V. (2010) Introduction: Film Languages in the European Collective Memory. Comunicar, 35, XVIII, 10-13.

Vala, J., Lopes, D., \& Lima, M. (2008). Black Immigrants in Portugal: LusoTropicalism and Prejudice. Journal of Social Issues, 64 (2), 287-302.

Walder, D. (2011) Postcolonial nostalgias: writing, representation and memory. New York: Routledge.

Isabel Macedo has a graduation and a master in Education Sciences, specialization in Sociology of Education, from the University of Minho. She is currently in the doctoral program in Cultural Studies in the field of Intercultural Communication, developing the project "Migrations and identity in Portuguese documentary films". Her main research interests combine the fields of memory studies, cultural studies and 
intercultural communication. She is researcher at the Communication and Society Research Centre (CECS) and scholarship from the Portuguese National Foundation for Science and Technology (FCT).

isabelmaced@gmail.com

Rosa Cabecinhas is Associate Professor at the Social Sciences Institute of University of Minho. Currently, her research interests include diversity and intercultural communication, social memory, social representations, social identity, stereotypes and social discrimination. She is author of "Preto e Branco: A naturalização da discriminação racial” (Paperback, 2007) and co-editor of "Comunicação Intercultural: Perspectivas, Dilemas e Desafios” (Paperback, 2008); “Narratives and Social Memory: theoretical and methodological approaches" (e-Book, 2013), and "Interfaces da Lusofonia" (e-Book, 2014).

cabecinhas@ics.uminho.pt

\section{Appendix A}

\section{Brief biography of the filmmaker António Escudeiro}

António Escudeiro was born on July 2, 1933, in Lobito, Angola. He was forced to leave Angola in 1975, aged 42. After three decades in Portugal, he returned to Angola to film the documentary "Goodbye, until Tomorrow". António Escudeiro is cinematographer and filmmaker. He features about 45 works as a cinematographer, with 35 years dedicated to Cinema: short films, feature films, documentaries and fiction - plus about 250 commercials. Paulo Rocha, António de Macedo, José Fonseca e Costa, José Manuel Lopes, Jorge Silva and Fernando Vicente Lopes are some of the filmmakers he worked with throughout his career. In recent years he has dedicated himself to the development and production of documentaries, area where he feels more freedom. The latest films directed by him were: Speed Sedimentation (2008), See, Listen Macau (2001), The Diopters of Elisa (2002); I Saw the Light Lost In Country (1999); We Separated (1999); For Josefa (1991), and Goodbye, until Tomorrow (2007).

\section{Film Synopsis - Goodbye, until Tomorrow}

António Escudeiro was born, raised and worked in Angola, until the day he was forced to go to Portugal. The return to Angola only became reality 32 years later, "Goodbye until tomorrow" is the portrait of this return, where are intersected and confronted two visual worlds: the memoirs of the director and the current Angola. 
(Source: http://www.realficcao.com/php/producao_2007.php)

\section{Appendix B}

\section{Brief biography of the filmmaker Diana Andringa}

Diana Andringa was born in 1947 in Dundo, northern Angola, the center of one of the most important mining companies, Diamang (a company exploiting Diamond mines in Angola). She is white, daughter of an engineer working at Diamang. The author came to Portugal in 1958 (aged 11) where she completed high school, and chose to study medicine at university. However, student arrests, contact with hospitalized children and the floods of 1967 led her to choose journalism instead of medicine.

Her first journalistic experience came through Vida Mundial (World Life) magazine in 1968/69, until a collective dismissal obliged her to find other work. She then worked as copy-writer at an advertising agency, an experience interrupted by her arrest by the International and State Defence Police (PIDE) in January 1970. Released in September 1971, she worked in journalism and advertising activities. She joined RTP - Portuguese Public Radio and Television, in 1978, working there for 23 years. In the meantime, she wrote articles for newspapers and radio. She also holds a PhD in Sociology from ISCTE - Lisbon University Institute, since 2012.

Currently Diana Andringa is an independent documentary producer. Some of her most recent films are: "East Timor: The Crocodile Dream" (2002), "The beach rampage that never was" (2005), "This is our blood, our life" (2005), "Back to the Crocodile Country" (2006), "The Two Sides of War" (co-directed with Flora Gomes - 2007) and "Dundo, Colonial Memory" (2009). These films share common themes; all seek to disclose the colonial past, the struggles for independence and the memories of those who lived conflict experiences.

\section{Film Synopsis - Dundo, Colonial Memory}

The film begins with photographs of Diana Andringa, when she was a child in Dundo. As she shows them to her daughter, she explains what Diamang was. While showing her birth certificate she tells her daughter that as she had been born in Angola, she was considered a "second class citizen" in Portugal. She explains how the memories of her childhood in Dundo marked her and how those same memories led her to fight for the independence of Angola.

In the cinemathèque archive, Diana Andringa found older films about Dundo that showed images of its sponsors, the tennis games and entertainment organized by Diamang in an atmosphere of racial segregation. The images included in the Diana Andringa's documentary illustrate the racial policies of the company. At Diamang's annual lunch for fomer employees, Diana Andringa collected some memories of the company. She found the image these people portrayed of the company strange and so left for Dundo with her daughter, to confront her memories.

(Source: synopsis adapted from http://www.lxfilmes.com/pt/documentario/item/dundo- 
Revista Lusófona de Estudos Culturais | Lusophone Journal of Cultural Studies Vol. 2, n.1

memoria-colonial.html;

http://www.comunicacao.uminho.pt/cecs/publicacoes.asp?startAt=2\&categoryID=924\&newsI

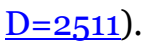

